\title{
Laryngeal Chondrosarcoma. Report of a Rare Case with Chronic Cough
}

\author{
Yu. Rangachev, Tsenev Iv. \\ Tsaritsa Yoanna-ISUL University General Hospital for Active Treatment, \\ Medical University - Sofia
}

\section{Introduction}

Chondrosarcomas of larynx are rare tumors, which represent approximately $0.5-2 \%$ of all laryngeal neoplasms. The chondrosarcomas in the area of head and neck represent only $10 \%$ of all chondrosarcomas in the body. According to data from the Registry of National Royal Throat, Nose, and Ear Hospital of London only 12 cases of laryngeal chondrosarcoma were found for a period of 24 years, which represents the biggest series described so far in Europe. Data of about 250 cases of laryngeal chondrosarcoma were diagnosed, described, and published for the period from 1816 to 2003, which was found based on a review of references. The chondrosarcoma is the fourth most frequent tumor, originating from cartilaginous tissue. The main localizations in the whole body are the pelvis and lower extremities. In particular, only $10 \%$ of the cases are in the region of the neck and head. The most frequent localizations in the region of the head and neck are the mandible and larynx. The chondrosarcoma is the most frequent sarcoma of the larynx and it differs by survival from the other tumors.

\section{Localization}

It originates most frequently from the cricoid cartilage (hyaline cartilage-origin) - this is the origin of the tumor in $70-80 \%$ of the cases. In $15-17 \%$ of the cases the origin is the thyroid cartilage, in 5-8\% - the arytenoid cartilage, in $2-2.5 \%$ - the epiglot- tis (elastic cartilage - origin), and in $1 \%$ - the rest cartilages.

\section{Epidemiology}

The ratio male/female is equal to $3.6 / 1$ with predomination during the sixth decade.

\section{Etiology}

The etiology is not known and it is accepted that there is no relation with smoking and alcohol consumption.

\section{Clinical manifestations}

Typical presentation of chondrosarcoma is the slow progress of the symptoms (with years) due to the slow growth of the tumor. The main symptoms from the larynx are: change of voice (dysphonia), stridor, difficult breathing (dyspnea), disturbance of swallowing (dysphagia - more rarely), as well as visible change of the contours of the larynx and neck, in case of a tumor formation growing extralaryngeally.

\section{Diagnosis}

From the status: As an objective finding, the chondrosarcoma is found as a tumor mass localized mainly subchondrally, covered by normal mucous membrane, and with hard consistence, which makes it difficult for taking of biopsy. 
Imaging methods: A valuable method for the diagnosis is the computed axial tomography. It shows the areas of calcification and the multiple focality of the process.

\section{Pathological anatomy}

The chondrosarcomas are hardly distinguishable from the chondromas. The histological diagnosis is based on the criteria of malignancy, developed by Liechtenstein and Jaffe (1943).

Three grades of malignancy are described, depending on the number of mitoses, atypism in the form and size of the nuclei and cells, as well as in the presence of mono- and multi-nucleated giant cartilaginous cells. They are viewed as follows:

- grade 1-(60-70\%) good differentiation

- grade 2 - (10-15\%) moderate differentiation

- grade $3-(5-10 \%)$ poor differentiation

Grade 2 and grade $3(5-10 \%)$ are comparatively rare findings.

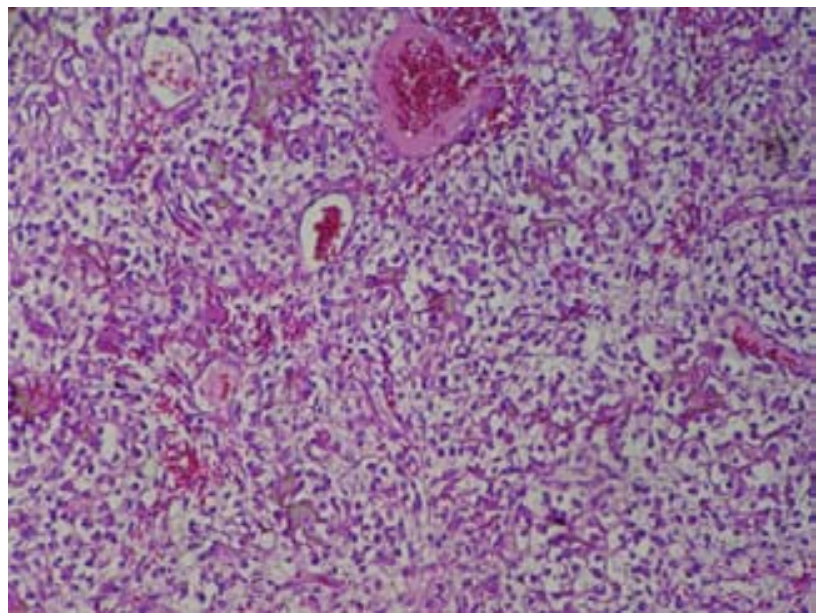

Figure 1. Mokhtari and Mirafsharieh Head \& Neck Oncology 2012 4:13 doi:10.11866/1758-3284-4-13

(Clear cell chondrosarcoma of the head and neck; Sepideh Mokhatari and Abbas Mirafsharieh; Head \& Neck Oncology 2012, 4:13)

\section{Treatment}

After the diagnosis is confirmed, surgical treatment follows. A conservative method is accepted by most authors in cases of first grade tumor, with performing of excision of the tumor. Laryngectomy is performed in the following cases: bigger tumors, which do not allow organ preservation surgery; relapses; and grade 2 and 3.

There are several possibilities for conservative surgical intervention - extirpation with carbon dioxide laser, open surgical intervention.
Chemo- and radiotherapy are non-effective in the treatment of chondrosarcomas.

\section{Prognosis}

$30-40 \%$ of relapses are reported in the references, usually related to grade 2 and 3 . The metastases are not frequent and are observed in $2-10 \%$ of the cases. As a result of that, and also of the slow growth of the tumor, survival of more than 5 years is observed in $90 \%$ of the cases. The relapses do not change the survival.

\section{Clinical case}

We report a clinical case of a male patient of 62 years, who was admitted at this Clinic with a complaint of continued and dry cough, accompanied by irritation of throat for several months. Patient did not report of smoking and systematic alcohol consumption.

Data from status: A formation was visualized upon indirect laryngoscopy in the subchondral space with sizes of $2.5 \times 2.0 \mathrm{~cm}$, covered by normal mucous membrane.

The described formation was found on the performed computed axial tomography, originating from the plate of the cricoid cartilage with areas of calcification.

Due to the possible difficulties upon intubation, patient was previously tracheostomized with local anesthesia, and was intubated through the tracheostoma. The larynx was inspected under a microscope, however the solidity of the formation did not allow realization of biopsy. It was proceeded with open surgical intervention.

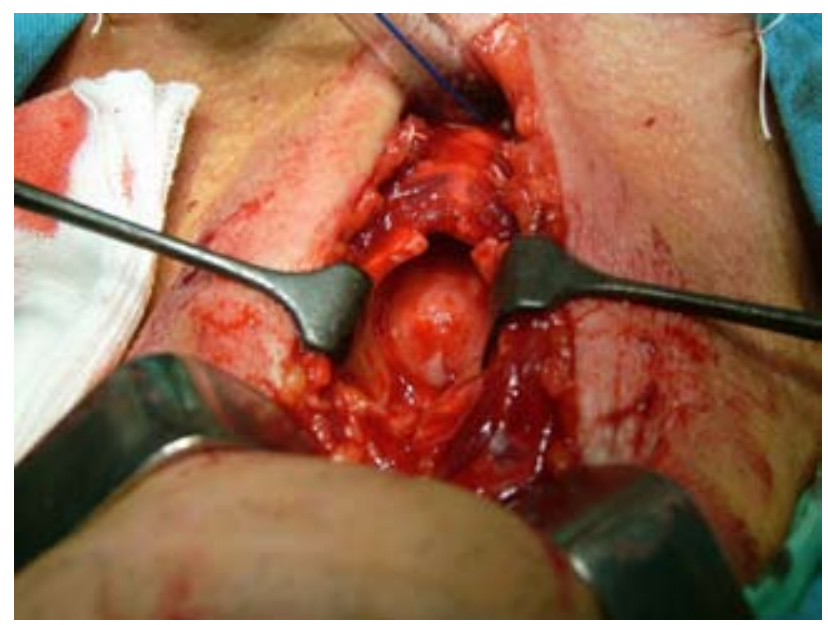

Figure 2. Surgical intervention. 


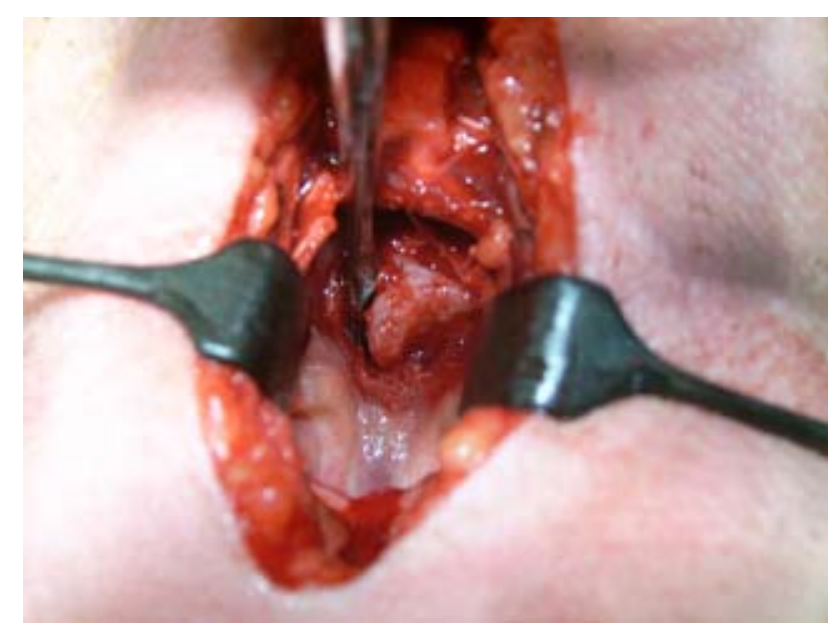

Figure 3. Surgical intervention.

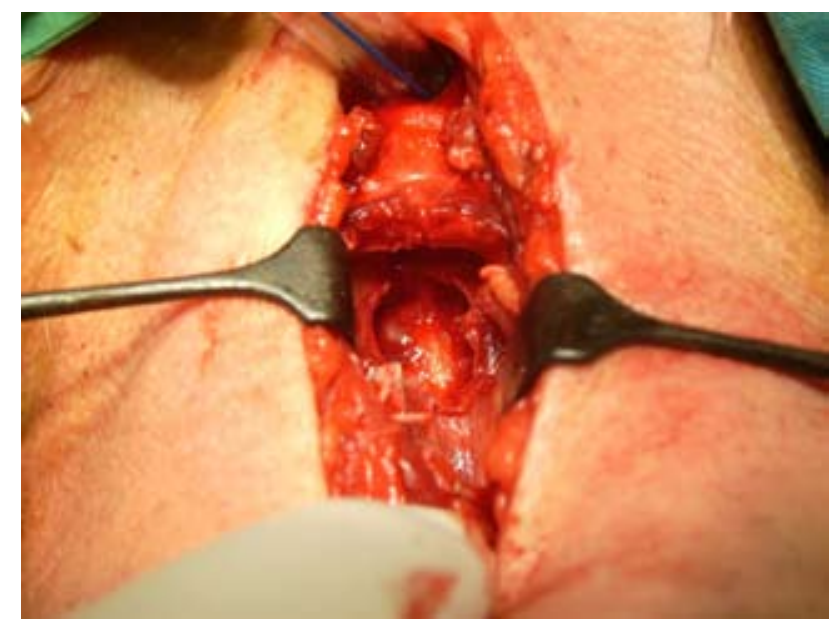

Figure 4. Surgical intervention removed chondrosarcoma.

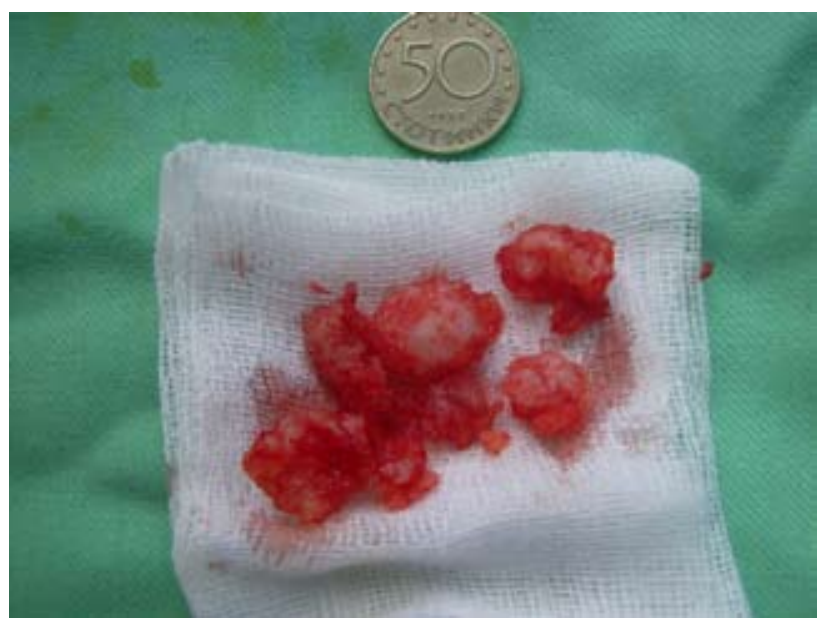

Figure 5. Removed chondrosarcoma.

The histological result demonstrated chondrosarcoma with good differentiation of grade 1 .

The extent of the performed organ preservation surgery was accepted as sufficient, considering the diagnosis. Patient was subject to regular follow-up after the surgical intervention. Based on the first follow-up examination performed a month after the surgery in August 2012, patient was in a much better general condition, the tracheostoma was surgically closed, and he breathed per vias naturales - only a small granulation persisted in the site of the removed tumor. At the second follow-up examination after one month, the granulation in the larynx had disappeared and there were no visible traces of the surgical intervention - the vocal folds were mobile upon phonation.

Patient has had a follow-up examination once every three months since then, and a control computed axial tomography was performed once yearly. The last follow-up examination was performed in August 2014, after computed axial tomography of neck, larynx, and upper mediastinum - no data were found of a relapse and metastases.

\section{Conclusion}

A few otolaryngologists, even among the most experienced in the treatment of tumors of the head and neck, see more than one patient with cartilagous neoplasm of the larynx during their career. On the whole, it is a very rare disease, which requires accurate knowledge regarding the differential diagnosis and the most appropriate treatment.

The laryngeal chondrosarcomas are rare tumors, which usually affect men in the sixth or seventh decade of their life.

In most of the cases the laryngeal chondrosarcoma is a slowly growing tumor with low grade of malignancy, which can easily be mistaken with chondroma.

The most frequently engaged cartilage is the cricoid cartilage.

The most frequent symptom is a husky voice and stridor, however a dyspnea, dysphagia, and presence of large mass in the neck could also be found.

The surgery is a main method of treatment. The volume of the surgery depends on the localization, size, and grade of impairment.

The aim of treatment must be organ preservation surgery except for the advanced forms, relapses, and tumor forms of poor differentiation. The conservative method achieves a good quality of life, which does not change the survival - it is usually high - of more than 5 years in more than $90 \%$ of the cases.

The role of radiotherapy as a main method of treatment is of secondary importance and requires further assessment. 


\section{References}

1 Oestereicher - Kedem Y, Dray TG, Damrose EJ. Endoscopic resection of low grade, subglottic chondrosarcoma. J Laryngol Otol. 2009 Jul 1: $1-3$

2 Rizzo S; Strinati F, Longari F, Bizzotti C, Altissimi G, Frenguelli A. Chondrosarcoma of the larynx: presentation of a case and review of the literature. Tumori 2008 Nov-Dec; 94(6): 864-8

3 Hong P, Taylor Sm, Trites JR, Bullock M, Nasser JG, Hart RD. Chondrosarcoma of the head and neck: report of 11 cases and literature review. J Otolaryngol Head Neck Surg 2009 Apr; 38(2): 279-85

4 Leclerc JE Chondrosarcoma of the larynx: case report with a 14-year follow-up, J Otolaryngol Head Neck Surg 2008 Oct : 37(5): E 143-7

5 Bathala S, Berry S, Evans RA, Brodie S, Altaan O. Chondrosarcoma of larynx: review of literature and clinical experience. J Laryngol Otol. 2008 Oct; 122(10): 1127-9

6 S. Berry, J. Addams-Williams, H. Khalil, S. Armstrong, K. Denton \& D. Baldwin: Chondrosarcoma of the larynx: The Internet Journal of Otorhinolaryngology, 2003 Volume 2 Number 2

7 Wippold FJ, Smirniotopoulos JG, Morgan CJ, et al. Chondrosarcoma of the larynx: CT features. AJNR Am J Nouroradiol 1993;14: 453-459 


\title{
Ларингеален хондросарком. Представяне на рядък случай на хронична кашлица
}

\author{
Ю. Рангачев, Ценев Ив. \\ УМБАЛ „Царица Йоанна-ИСУЛ“, МУ-София
}

\section{Въведение}

Хондросаркомите на ларинкса са редки тумори, които представляват приблизително 0,5-2\% от всички ларингеални новообразувания. Хондросаркомите в областта на главата и шийния регион представляват само $10 \%$ от всички хондросаркоми в тялото. По данни на регистъра към Националната Кралска УНГ-болница - Лондон, за период от 24 години са открити само 12 случая на ларингеален хондросарком, което представлява най-голямата описана в Европа серия. При преглед на литературата се установи, че за периода от 1816 до 2003 г. са били диагностицирани, описани и публикувани данни за около 250 случая на ларингеален хондросарком.

Хондросаркомът е четвъртият по честота тумор, произхождащ от хрущялна тькан. Основни локализации за цялото тяло са тазът и долните крайници, като само $10 \%$ от случаите са от областта на главата и шията. Най-честите локализации в областта на главата и шията са долната челюст и ларинксът. Хондросаркомът е най-честият сарком на ларинкса и се различава от останалите по преживяемостта.

\section{Локализация}

Най-често изхожда от крикоидния хрущял. В $70-80 \%$ от случаите туморът изхожда от крикоидния хрущял (хиалинен), 15-17\% - от щитовидния хрущял, 5-8\% - от аритеноида, 2-2,5\%
- от епиглотиса (еластичен хрущял) и $1 \%$ - от останалите хрущяли.

\section{Епидемиология}

Съотношение мъже/жени $=3.6 / 1$ с доминиране през шеста декада.

\section{Етиология}

Етиологията не е известна и се приема, че не е свързана с тютюнопушене и употреба на алкохол.

\section{Клинични прояви}

Характерно за хондросаркома е бавното прогресиране на симптомите, с години, поради бавния растеж на тумора. За ларинкса основните симптоми са: промяна в гласа - дисфония, стридор, затруднение в дишането - диспнея, нарушение в гълтането - дисфагия (по-рядко), както и видима промяна в контурите на ларинкса и шията, при Ту формация растяща екстраларингеално.

\section{Диагноза}

От статуса: Обективно хондросаркомът обикновено се открива като туморна маса, разположена предимно субхордално, покрита от нормална лигавица и твърда консистенция, което я прави трудна за биопсиране.

Образни методи: Ценен метод в диагнозата е КАТ, показвайки зоните на калцификация и мултифокалност на процеса. 


\section{Патоанатомия}

Хистологично хондросаркомите могат да бъдат трудно различими от хондромите. Хистологичната диагноза се поставя на базата на критерии за малигненост, разработени от Liechtenstein and Jaffe (1943).

Описани са 3 степени на малигненост в зависимост от броя митози, атипизъм във формата и размера на ядрата и клетките, както и в наличието на моно- и мултинуклеарни гигантски хрущялни клетки. Така се разглеждат:

- Grade 1 - (60-70\%) добре диференциран

- Grade 2 - (10-15\%) умерено диференциран

- Grade 3 - (5-10\%) ниско диференциран

- Grade 2 и Grade 3 - (5-10\%) са сравнително редки находки.

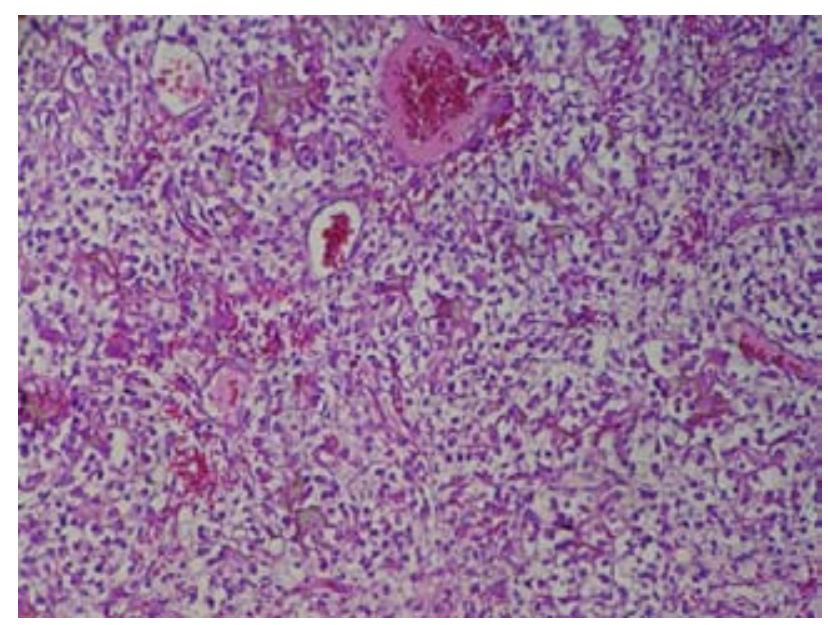

Фиг. 1. MokhtariandMirafsharieh Head \&Neck Oncology 2012 4:13 doi:10.1186/1758-3284-4-13

(Clear cell chondrosarcoma of the head and neck; Sepideh Mokhatari and Abbas Mirafsharieh; Head \& Neck Oncology 2012, 4:13)

\section{Лечение}

След поставяне на диагнозата лечението е хирургично. При grade 1 се приема консервативен подход от повечето автори, като се прави ексцизия на тумора. Ларингектомия се прави при по-големи тумори, непозволяващи органосъхраняваща операция, при рецидиви и при grade 2 и 3.

За консервативна хирургична интервенция съществуват няколко възможности - екстирпация с $\mathrm{CO}_{2}$ лазер, отворена хирургична интервенция.

Химио- и лъчетерапията са неефективни в лечението на хондросаркомите.

\section{Прогноза}

В литературата се докладват 30-40\% на рецидиви, обикновено свързани с grade 2 и 3 . Метастазите не са чести и се наблюдават при $2-10 \%$ от случаите. В резултат на това, както и на бавното нарастване на тумора преживяемост над 5 години се наблюдава при 90\%. Рецидивите не променят особено преживяемостта.

\section{Клиничен случай}

Представяме клиничен случай на 62-годишен пациент, постьпил в клиниката с оплакване от продължителна и суха кашлица, придружена с дразнене в гърлото от няколко месеца. Не съобщава за тютюнопушене и системна консумация на алкохол.

От статуса: При индиректна ларингоскопия се видя формация в субхордалното пространство с размери около 2,5 х 2.0 см., покрита от нормална лигавица.

На направената КАТ се откри описаната формация, изхождаща от плочката на пръстеновидния хрущял със зони на калцификация.

Поради възможни трудности при интубация пациентьт беше предварително трахеостомиран с локална анестезия и интубиран през трахеостомата. Огледа се ларинксът под микроскоп, но твърдостта на формацията не позволи реализирането на биопсия. Пристъпи се към отворена оперативна интервенция.

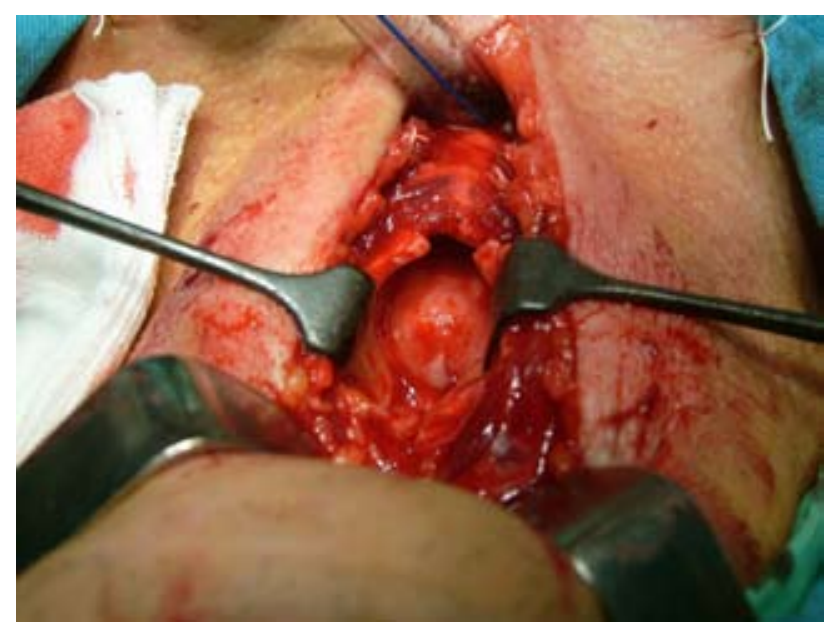

Фиг. 2. Оперативна интервенция 


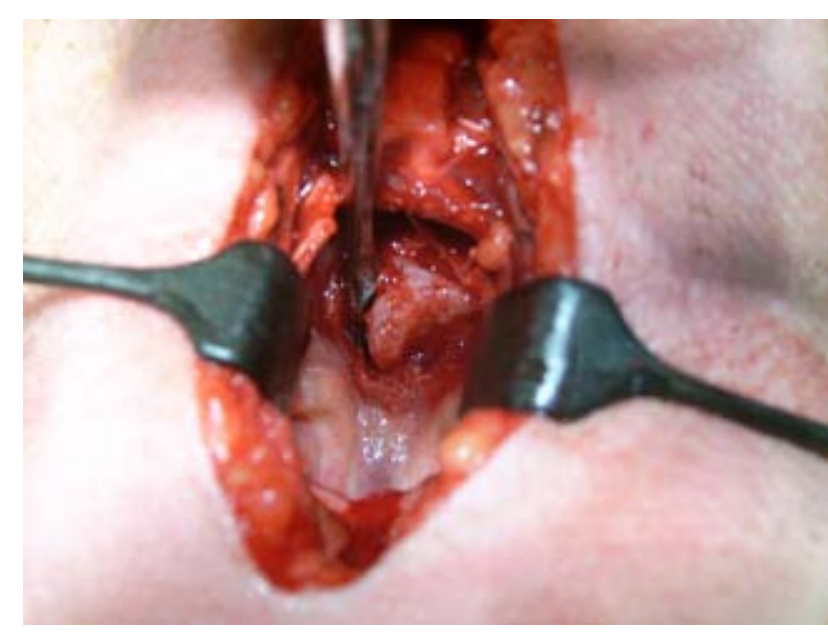

Фиг. 3. Оперативна интервенция

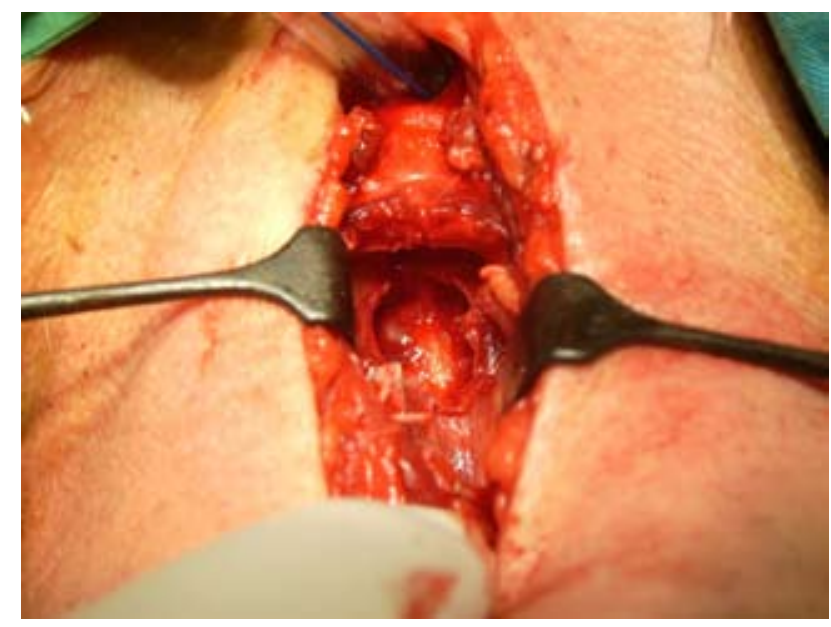

Фиг. 4. Оперативна интервенция отстранен Chondro Sa

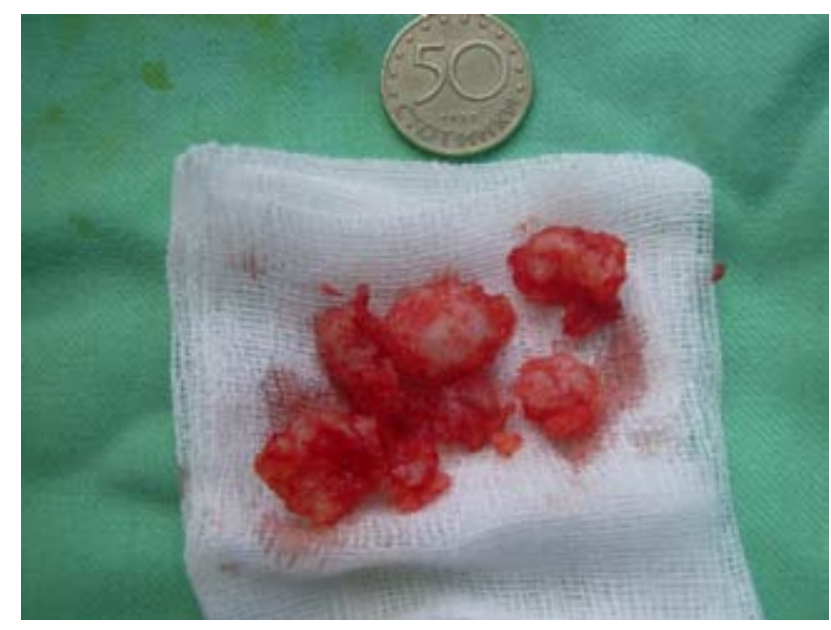

Фиг. 5. Отстраненият хондросарком

Хистологичният резултат показа добре диференциран хондросарком - grade- 1 .

Обемът на извършената органосъхраняваща операция се прие за достатъчен с оглед диагнозата. След оперативната интервенция пациентът подлежи на редовно проследяване. При първия контролен преглед, извършен месец след операцията през август 2012 година, пациентът бе в много-добро общо състояние, трахеостомата е затворена и диша ,per viasnaturales“, само персистира малка гранулация на мястото на отстранения Ту. На втория контролен преглед след месец гранулацията в ларинкса бе изчезнала и видимо няма следи от оперативната интервенция - гласните гънки са подвижни при фонация.

Оттогава пациентът се контролира на 3 месеца, като веднъж годишно прави контролен КАТ. Последният контролен преглед е правен през август 2014 година, след КАТ на шия, ларинкс и горен медиастенум - без данни за рецидив и метастази.

\section{Заключение}

Малко оториноларинголози, дори и най-опитните в лечението на туморите на главата и шията, виждат повече от 1 пациент с хрущялна неоплазма на ларинкса по време на кариерата си. Това като цяло е много рядко заболяване, което изисква акуратни знания по отношение на диференциалната диагноза и най-подходящото лечение.

Ларингеалните хондросаркоми са редки тумори, които обикновено засягат мъже в шесто-седмо десетилетие.

В повечето случаи ларингеалният хондросарком е бавно растящ тумор с ниска степен на малигненост, който лесно може да бъде сбъркан с хондром.

Най-често ангажираният хрущял е cartilago cricoidea.

Най-честият симптом е дрезгавост на гласа и стридор, но може да има диспнея, дисфагия и наличие на обемна маса на шията.

Хирургията е основният метод на лечение. Обемът на операцията зависи от локализацията, размера и степента на увреждането.

Лечението трябва да бъде насочено към органосъхраняваща операция освен при напредналите форми, рецидивите и ниско диференцираните варианти. С консервативния подход се постига добро качество на живот, като не се променя преживяемостта, която обикновено е висока, над 5 години при повече от 90\% от случаите.

Ролята на радиотерапията като основен метод за лечение е второстепенна и се нуждае от понататъшна оценка. 


\section{Библиография}

1. Ценев Ив., Марев Д., Ценев Е., Недев П. Актуални проблеми при лечението на ларингеалния карцином (продължение - симптоми и диагностични техники). Международен бюлетин по оториноларингология. 2006, бр. 1, 47-50

2. Ценев Ив., Марев Д., Ценев Е., Недев П. Актуални проблеми при лечението на ларингеалния карцином (продължение - консервативно и хирургично лечение). Международен бюлетин по оториноларингология. 2006, бр. 1, 53-56

3. Деспотов, О. Съвременни възможности на ендоназалната синусна хирургия. София, Докторска дисертация, 2000.

4. Деспотов, О. Съвременно лечение на остеомите на фронталните синуси. - Ото-рино-ларингология, 5, 2001, 4, 35-38.

5. Запрянов, 3., С. Кумчев, С. Генова, С. Джамбазова, Г. Иванов, И. Биволарски, Б. Калнев. Морфологични и биологични параметри при първичен и рецидивен интракраниален хондросарком. - Мед. преглед, 42, 2006, 2, 107-110.

6. Маламов, М., Е. Богданов, Г. Едрев, О. Деспотов. Хирургично лечение на остеомите на фронталните синуси. - В: Научни трудове - Ямбол, 1985 г.

7. Маринова, Л., И. Михайлова, Р. Георгиев. Лъчево-индуциран хондросарком - клиничен случай от нашата практика. - Рентгенол. и радиол., 52, 2013, 4, 290-294.

8. Михова, А., Т. Соколов, Ц. Михова. Имунохистохимия и диференциация на хондросаркома. - Ортоп. и травматол., $33,1996,1,35-38$.

9. Соколов, Т. Лечението на хондросаркомата. - Ортоп. и травматол., 44, 2007, 1-2, 7-19.

10. Oestereicher - Kedem Y, Dray TG, Damrose EJ. Endoscopic resection of low grade, subglottic chondrosarcoma. J Laryngol Otol. 2009 Jul 1: $1-3$

11. Rizzo S; Strinati F, Longari F, Bizzotti C, Altissimi G, Frenguelli A. Chondrosarcoma of the larynx: presentation of a case and review of the literature. Tumori 2008 Nov-Dec; 94(6): 864-8

12. Hong P, Taylor Sm, Trites JR, Bullock M, Nasser JG, Hart RD. Chondrosarcoma of the haed and neck: report of 11 cases and literature review. J OtolaryngolHaed Neck Surg 2009 Apr; 38(2): 279-85

13. Leclerc JE Chondrosarcoma of the larynx: case report with a 14- year follow-up, J OtolaryngolHaed Neck Surg 2008 Oct : 37(5): E 143-7

14. Bathala S, Berry S, Evans RA, Brodie S, Altaan O. Chondrosarcoma of laryx: review of literature and clinical experience. J Laryngol Otol. 2008 Oct; 122(10): 1127-9

15. S. Berry, J. Addams-Williams, H. Khalil, S. Armstrong, K. Denton \& D. Baldwin: Chondrosarcoma of the larynx: The Internet Journal of Otorhinolaryngology, 2003 Volume 2 Number 2

16. Wippold FJ, Smirniotopoulos JG, Morgan CJ, et al. Chondrosarcoma of the larynx: CT features. AJNR Am J Nouroradiol 1993;14: 453-459 